\title{
NANOCOPPER EFFECT ON THE TOXICITY OF TEXTILE PRODUCTS
}

Babii V.F., Bren N.I., Pimushyna M.V., Kondratenko O.Ye. ВПЛИВ НАНОМІДІ НА ТОКСИЧНІСТЬ ТЕКСТИЛЬНИХ ВИРОБІВ

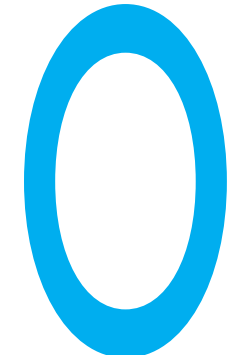

БАБІЙ В.Ф., БРЕНЬ H.I., ПІМУШИНА М.В., КОНДРАТЕНКО О.Є. ДУ «нститут громадського здоров'я ім. О.М. Марзєєва НАМН України», м. Київ

УДК 613.48:677.027.65$034.3: 648.6$

Ключові слова: наномідь, токсичність, текстильні вироби, індекс токсичності. станніми роками на ринку України почали з'являтися нові текстильні вироби закордонного виробництва (шкарпетки, рушники, білизна тощо), виготовлені за інноваційними технологіями з використанням «мідної нитки» - надчистого мідного нанопорошку, який рівномірно розподіляється у волокнах поліаміду або поліестеру. Саме нанотехнології дозволили отримати мідну пряжу «мідну нитку», яка у подальшому стала використовуватись у натуральних і синтетичних тканинах Технологія застосування «мідної нитки» у складі різноманітних тканин була розроблена Borkow G. і співавторами $[1,2]$. За свідченням виробників, текстильні вироби, виготовлені з використанням міді, мають низку корисних властивостей, зокрема дезінфікуючий (антибактеріальний, антивірусний, протигрибковий) ефект. За цією технологією у світі 3'явилося розмаїття побутових і промислових текстильних виробів, що містять мідь [3, 4]. Нині біоцидний ефект міді використовується у

\section{ВЛИЯНИЕ НАНОМЕДИ НА ТОКСИЧНОСТЬ ТЕКСТИЛЬНЫХ} ИЗДЕЛИЙ

Бабий В.Ф., Брень Н.И., Пимушина М.В., Кондратенко Е.Е. ГУ «Институт общественного здоровья им. А.Н. Марзеева НАМН Украины», Г. Киев

Цель работы. Определение токсиколого-гигиенических показателей текстиля, произведенного с использованием «медной нити", в соответствии с критериями оценки сырья и материалов для текстильных, кожаных, меховых изделий с целью обоснования условий их безопасного использования.

Материалы и методы. Объектом исследования были носочные изделия, изготовленные с применением «медных волокон». Для изучения общетоксического действия использовали метод суспензионной культуры подвижных клеток - сперматозоидов быка, а в качестве тест-функции - их подвижность. В основе метода лежит анализ изменения зависимости показателя подвижности сперматозоидов от времени.

Результаты. Оценка результатов испытаний осуществлялась путем сравнения полученных значений индексов токсичности для исследуемых образцов и допустимого интервала индекса токсичности. Исследуемый образец считали нетоксичным, если индекс токсичности омел значение от 70\% до 120\%. Результаты определения общетоксического действия текстильних изделий с «медными волокнами» (на примере носочных изделий) показали, что индекс токсичности составляет 78,7\%, что соответствует определению «нетоксично». Таким образом, исследуемые текстильные изделия, изготовленные с использованием «медной нити», не проявляют токсических свойств и являются безопасными для потребителей Ключевые слова: наномедь, токсичность, текстильные изделия, индекс токсичности.

(C) Бабій В.Ф., Брень Н.І., Пімушина М.В., Кондратенко О.Є. СТАТТЯ, 2016. виробництві текстилю, латексу, інших полімерних виробів, просочених оксидом міді $[1,2]$, антивірусних масок [3], тканин для перев'язки ран, що сприяють загоєнню ран [5], а також шкарпеток, що зберігають ноги пацієнтів, хворих на цукровий діабет, від інфекцій, оскільки останні є особливо сприйнятливими до інфекцій ступень ніг [6, 7].

Відомо, що на початку 2000-х років в Ізраїлі були проведені масштабні дослідження задля встановлення доцільності застосування шкарпеток, просочених оксидом міді, для екіпірування військових [8]. За результатами цього дослідження, шкарпетки, що містили волокна з оксиду міді, були рекомендовані як важлива частина персонального екіпірування військових Армії Оборони Ізраїлю. Таким чином, Ізраїль став першою країною, армія якої стала використовувати антимікробні шкарпетки, виготовлені на основі інноваційних технологій 3 використанням наноміді [8]. У подальшому використання шкарпеток, просочених оксидом міді, набуло поширення у багатьох арміях провідних країн світу: США, Великобританії, Китаю та інших. На сучасному ринку багатьох зарубіжних країн шкарпетки, виготовлені з застосуванням «мідних волокон», які призначені для захисту ніг від інфекцій, є поширеними і доступними для населення.

Введення в обіг на території нашої країни текстильних матеріалів, а також їх реалізація і використання, згідно 3 законодавством України щодо охорони здоров'я, має відбуватися за умови їх відповідності санітарно-токсикологічним показникам та гігієнічним нормативам для попередження можливого негативного впливу на здоров'я населення. Виходячи 3 цього метою цього дослідження було встановлення токсиколого-гігієнічних показників текстилю, виробленого з застосуванням «мідної нитки», відповідно до критеріїв оцінки сировини та матеріалів для текстильних, шкіряних, хутряних виробів 3 метою обґрунтування умов безпечного їх використання.

Матеріали та методи дослідження. Об'єктом даного дослідження були шкарпеткові вироби, виготовлені 3 застосуванням «мідних волокон». Матеріал, 3 якого виробляються такі шкарпетки, містить такі компоненти: поліестер - 61\% або нейлон - 
59\%; поліестер-купрон - 11\% або нейлон-купрон - 36\%; еластан - 3-5\%; бавовна - до 9\%.

Для дослідження загальнотоксичної дії використовували метод суспензійної короткочасної культури рухливих клітин сперматозоїдів бика, а в якості тест-функції - їхню рухливість [9]. В основі методу лежить аналіз зміни залежності показника рухливості сперматозоїдів від часу. Оцінка показника рухливості здійснюється підрахунком зміни інтенсивності світлового потоку при пересуванні сперматозоїдів через оптичну зону.

Експериментально встановлено, що між результатами оцінки загальної токсичності на цілісному організмі ссавців та цитотоксичністю для сперматозоїдів бика існує значний ступінь кореляції ( $r=0,83)$, що дозволяє визначати критерії екстраполяції результатів експериментів, отриманих за цим методом, на цілісний організм [10].

Для визначення індексу токсичності готували витяжку зразка шкарпеток. Для цього відповідно до методики моделювання водної витяжки при визначенні індексу токсичності зразок витримували у бідистильованій воді за температури $40^{\circ} \mathrm{C}$ протягом 24-х годин у співвідношенні маси зразка (m) до об'єму води (V) як 1 : 50 , де $m=8,0696$ г; $V=403,48$ мл.

Дослідження витяжок на токсичність проводили на аналізаторі токсичності АТ-05, що складався з блоку пробопідготовки та блоку вимірювання. У кожному експерименті використовували по 5 капілярів контрольного та досліджуваного розчину. Оцінка ступеня токсичності визначалася за величиною індексу токсичності $\mathrm{l}_{\mathrm{t}}$, яка дорівнює співвідношенню середнього часу рухливості сперматозоїдів у досліджуваному зразку та середнього часу їх рухливості у контрольному зразку.

Досліджуваний зразок готувався шляхом додавання до 100 мл водної витяжки 4 г глюкози та 1 г тризаміщеного цитрату натрію. Для визначення ступеня токсичності досліджуваного зразка порівнювали його з контрольним середовищем, яким був розчин глюкози (4\%) та цитрат натрію тризаміщений (1\%) у дистильованій воді (100 мл). Це ж контрольне

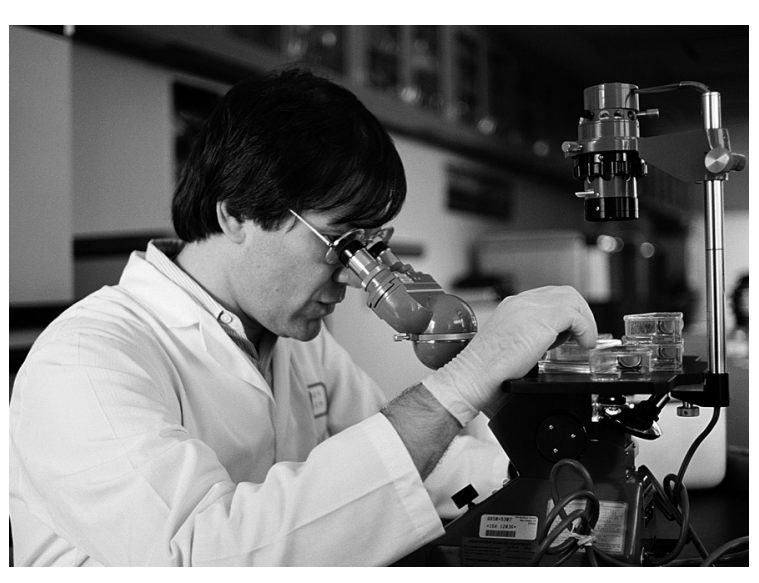

ГІГІЄНІЧНІ ПРОБЛЕМИ НАНОТЕХНОЛОГІЙ

середовище використовувалось як розчин для відтавання сперми. Після відтавання гранул сперматозоїдів протягом 5-7 хвилин у кожну пробірку 3 контрольним та досліджуваним розчинами додавали по 0,1 мл маточної суспензії сперматозоїдів.

Результати дослідження та їх обговорення. Оцінка результатів випробувань здійснювалась шляхом порівняння отриманих значень індексів токсичності для досліджуваних зразків та допустимого інтервалу індексу токсичності. Досліджуваний зразок вважали нетоксичним, якщо індекс токсичності мав значення від 70\% до $120 \%$.

Результати експерименту представлено у таблиці.

Результати визначення індексу токсичності шкарпеткових виробів: обсяг відтавання 0,8; кількість циклів - 16; індекс токсичності $\mathrm{I}_{\mathrm{t}}=78,7 \%$.

Величина індексу токсичності розраховується автоматично 3 урахуванням коефіцієнта кореляції $(r=0,83)$. Результати експерименту у графічному вигляді представлені на рисунку.

Як показали результати досліджень, у досліджуваному зразку індекс токсичності I $\mathrm{t}$ має значення 78,7\%, перебуває у межах 70-120\% та відповідає визначенню «нетоксично». Результати підтверджуються графіком, представленим на рисунку: площі фігур, утворених лініями контрольного та досліджуваного зразків, ідентичні, що свідчить про близькість значень рухливості сперматозоїдів.

Таким чином, результати визначення гострої токсичності наданого зразка шкарпеток методом in vitro показали, що за показником індексу токсичності шкарпеткові вироби, які виготовлені 3 застосуванням «мідної нитки», $€$ безпечними для споживачів.

\section{Висновок}

Отримані результати визначення загальнотоксичної дії

Таблиця

Динаміка зміни рухливості сперматозоїдів (у.о.) при визначенні індексу токсичності шкарпеткових виробів

\begin{tabular}{|c|c|c|c|c|c|c|c|c|c|c|}
\hline \multirow{2}{*}{ Цикл } & \multicolumn{5}{|c|}{ Контрольні серії } & \multicolumn{5}{c|}{ Дослідні серії } \\
\cline { 2 - 12 } & 1 & 2 & 3 & 4 & 5 & 1 & 2 & 3 & 4 & 5 \\
\hline 1 & 6756 & 6005 & 7194 & 6549 & 7034 & 6017 & 5391 & 5191 & 5629 & 5703 \\
\hline 2 & 6076 & 6110 & 7126 & 5942 & 6933 & 6241 & 5165 & 5092 & 4921 & 5651 \\
\hline 3 & 4930 & 6057 & 6018 & 5863 & 6582 & 4895 & 4327 & 5127 & 4875 & 5228 \\
\hline 4 & 3464 & 4989 & 4898 & 4459 & 5981 & 2902 & 4341 & 3703 & 3522 & 3253 \\
\hline 5 & 1341 & 4021 & 4453 & 1995 & 4894 & 824 & 2974 & 1990 & 2115 & 1207 \\
\hline 6 & 162 & 1864 & 4082 & 557 & 4299 & 92 & 2408 & 711 & 968 & 601 \\
\hline 7 & 0 & 730 & 3642 & 294 & 3835 & 0 & 1464 & 164 & 583 & 112 \\
\hline 8 & 0 & 241 & 2919 & 4 & 2540 & 0 & 580 & 1 & 103 & 0 \\
\hline 9 & 0 & 119 & 2067 & 0 & 2170 & 0 & 307 & 0 & 0 & 0 \\
\hline 10 & 0 & 29 & 1657 & 0 & 1541 & 0 & 95 & 0 & 0 & 5 \\
\hline 11 & 0 & 0 & 1195 & 0 & 1068 & 0 & 20 & 0 & 0 & 0 \\
\hline 12 & 0 & 0 & 824 & 0 & 553 & 0 & 0 & 0 & 0 & 0 \\
\hline 13 & 0 & 0 & 421 & 0 & 519 & 0 & 18 & 0 & 0 & 0 \\
\hline 14 & 0 & 0 & 384 & 0 & 366 & 0 & 0 & 0 & 0 & 0 \\
\hline 15 & 0 & 0 & 192 & 0 & 97 & 0 & 0 & 0 & 0 & 0 \\
\hline 16 & 0 & 0 & 106 & 0 & 40 & 0 & 0 & 0 & 0 & 0 \\
\hline
\end{tabular}


NANOCOPPER EFFECT ON THE TOXICITY OF TEXTILE PRODUCTS

Babii V.F., Bren N.I., Pimushyna M.V., Kondratenko O. Ye. State Institution "O.M. Marzeiev Institute for Public Health of the National Academy of Medical Sciences of Ukraine"

Objective. We determined the toxicological and hygienic indicators of textiles produced using "a copper filament" in accordance with the criteria of the evaluation of raw material and textile, leather, fur ones and products of them to justify the conditions for their safe use.

Materials and methods. Hosiery produced with "copper fibers" was the object of the study. For the study of general toxic effect we used a method of the suspended culture of motile cells-bull sperm, and their motility was a test function. The method is based on the analysis of the change of the dependence of sperm motility index from time.

Results. Evaluation of test results was carried out comparing the obtained toxicity indices for the test samples and the allowable range of toxicity index. The studied sample was considered as non-toxic one if index of toxicity had a value from $70 \%$ to $120 \%$. Results of the determination of general toxic effect of textile products with "copper fibers" ( by way of example of hosiery) showed that the index of toxicity made up $78.7 \%$ that agrees with the definition of "non-toxic". Thus studied textile products, made with "copper filament", do not manifest toxic properties and are safe for consumers.

Keywords: nanocopper, toxicity, textile products, index of toxicity. текстильних виробів з «мідними волокнами» (на прикладі шкарпеток), проведені за методом експрес-оцінки загальної токсичності з використанням культури клітин, показали, що індекс токсичності становить 78,7\%, що перебуває у межах від 70\% до 120\% і відповідає визначенню «нетоксично». Таким чином, досліджувані текстильні вироби не проявляють токсичних властивостей та є безпечними для споживачів.

ЛІТЕРАТУРА

1. Borkov G. Putting copper into action: copper-impregnated products with potent biocidal activities / G. Borkov, J. Gabbay // FASEB J. - 2004. - Vol. 18, № 14. - P. 1728-1730.

2. Copper oxide impregnated textiles with potent biocidal activities / J. Gabbay, J. Mishal, E. Magen et al. // Journal of Industrial Textiles. - 2006. Vol. 35, № 4. - P. 323-335.

3. A novel anti-influenza copper oxide containing respiratory face mask / G. Borkov, S.S. Zhou, T. Page, Y. J. Gabbay // PLOS ONE. - 2010. - Vol. 5, № 6. - P. 1932-6203.

4. Borkov G. Copper oxide

impregnated wound dressing: biocidal and safety studies /

G. Borkov, N. Okon-Levy, Y.J. Gabbay //Wounds. - 2010. - Vol. 22, № 12. - P. 301-310.

5. Molecular mechanisms of enhanced wound healing by copper oxide-impregnated dressings / G. Borkov, Y.J. Gabbay, R. Dardik et al. // Wound. Repair Regen. - 2010. - Vol. 18, № 2. - P. 266-275.

6. Zatcoff R.C. Treatment of tinea pedis with socks containing copper impregnated fibers / R.C Zatcoff, M.S. Smith

G. Borkov // The Foot. - 2008. - Vol. 18. - P. 136-141.

7. Borkov G. Reducing the risk of skin pathologies in diabetics by using copper impregnated socks / G. Borkov, R.C. Zatcoff, Y.J. Gabbay // Med. Hypotheses. - 2009. - Vol. 73, № 4. P. 883-886.

8. Borkow G. Protection of Soldiers' Feet by Copper Oxide Impregnated Socks // Advances in Military Technology. - 2013.

- Vol. 8, № 2. - P. 1-8.

9. Пааташвилли К.А. Влияние некоторых синтетических сред и различных химических соединений на биологические свойства сперматозоидов

Рисунок

\section{Визначення індексу токсичності шкарпеткових виробів}

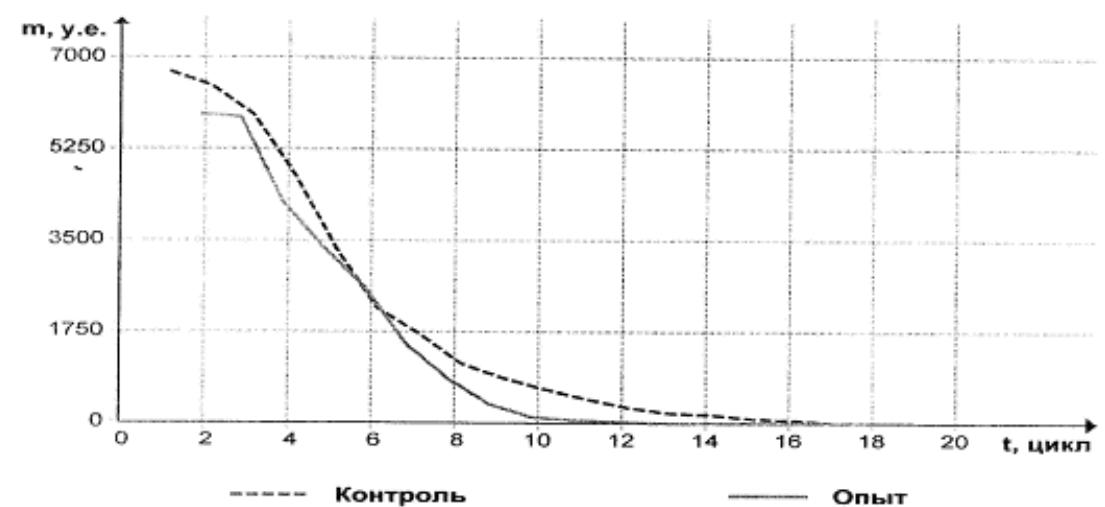

Примітки:

m - показник рухливості сперматозоїдів; $t$ - кількість циклів. кроликов и быков : автореф. дис. канд. биол. наук. - Л. ; Пушкин, 1973. - 23 с.

10. Ротенберг Ю.С. О наличии корреляций между токсичностью химических агентов и их ингибиторной активностью для изолированных митохондрий // Бюл. экспер. биол. и мед. 1974. - № 7. - С. 65-67.

REFERENCES

1. Borkov G., Gabbay J. FASEB J. $2004 ; 18(14)$ : 1728 1730.

2. Gabbay J., Mishal J., Magen E., Zatcoff R.C., Shemer-Avni Y., Borkov G. Journal of Industrial Textiles. 2006 ; 35 (4) : 323-335 .

3. Borkov G., Zhou S.S., Page T., Gabbay Y.J. PLOS ONE. $2010 ; 5$ (6) : 1932-6203.

4. Borkov G., Okon-Levy N., Gabbay Y.J. Wounds. 2010 ; 22 (12) : 301-310.

5. Borkov G., Gabbay Y.J., Dardik R., Eidelman R., Ikher S., Huszar M. Wound. Repair Regen. 2010 ; 18 (2) : 266-275.

6. Zatcoff R.C., Smith M.S., Borkov G. The Foot. 2008 ; 18 : 136-141.

7. Borkov G., Zatcoff R.C., Gabbay Y.J. Med. Hypotheses. 2009 ; 73(4) : 883-886.

8. Borkow G. Advances in Military Technology. 2013 ; 8 (2) : 1-8.

9. Paatashvilli K.A. Vliianie nekotorykh sinteticheskikh sred i razlichnykh khimicheskikh soedinenii na biologicheskie svoistva spermatozoidov krolikov i bykov : avtoref. diss. kand. biol. nauk [Impact of Some Synthetic Mediums and Various Chemical Compounds on the Biological Properties of Rats' and Oxen's Spermatozoon]. Leningrad (Pushkin); 1973 : 23 p. (in Russian).

RotenbergYu.S. Biul. eksperim. biol. i med. $1974 ; 7$ : 65-67 (in Russian).

Надійшла до редакції 02.12.2015 